\title{
Permeation and separation studies on microporous sol-gel modified ceramic membranes
}

\author{
R.S.A. de Lange, J.H.A. Hekkink, K. Keizer *, A.J. Burggraaf \\ Laboratory for Inorganic Chemistry, Materials Science and Catalysis, Faculty of Chemical Technology, University of \\ Twente, P.O. Box 217, 7500 AE Enschede, Netherlands
}

Received 29 March 1994; accepted 12 December 1994

\begin{abstract}
Permeation and separation experiments with $\mathrm{H}_{2}, \mathrm{CO}_{2}, \mathrm{O}_{2}, \mathrm{~N}_{2}, \mathrm{CH}_{4}$ and isobutane with microporous sol-gel modified supported ceramic membranes were performed to determine the gas transport characteristics and the hydrogen separation performance of these membranes. It is found that the permeation is activated, and for defectfree membranes the apparent activation energies are in the ranges $13-15$ and $5-6 \mathrm{~kJ} \mathrm{~mol}^{-1}$ for $\mathrm{H}_{2}$ and $\mathrm{CO}_{2}$, respectively. Correction for the pressure drop over the support results in apparent activation energies for the silica top-layer on the order of 17-22 and $10-15 \mathrm{~kJ} \mathrm{~mol}^{-1}$ for $\mathrm{H}_{2}$ and $\mathrm{CO}_{2}$ respectively. Due to the very thin top-layer, the permeation is relatively high, with representative values of $6 \cdot 10^{-7}$ and $20 \cdot 10^{-7} \mathrm{~mol} \mathrm{~m}^{-2} \mathrm{~s}^{-1} \mathrm{~Pa}^{-1}$ for $\mathrm{H}_{2}$ at 25 and $200^{\circ} \mathrm{C}$, respectively. The $\mathrm{H}_{2}$ permeation is almost pressure-independent up to pressures of at least 5 bar. Typical separation factors for $\mathrm{H}_{2}-\mathrm{CH}_{4}$ and $\mathrm{H}_{2}$-isobutane are approximately $\approx 40$ and $\approx 200$, respectively, at $200^{\circ} \mathrm{C}$ for highquality membranes. For moderate-quality membranes the $\mathrm{H}_{2}-\mathrm{CH}_{4}$ separation factor is around 10 , while the $\mathrm{H}_{2}$-isobutane separation factor remains at a high value of around 100 at $200^{\circ} \mathrm{C}$ and 120 at $300^{\circ} \mathrm{C}$.
\end{abstract}

Keywords: Gas separation; Gas transport; Microporous ceramic membranes: Sol-gel process

\section{Introduction}

Microporous $\left(r_{\text {pore }}<1 \mathrm{~nm}[1]\right)$ ceramic membranes are very attractive systems for gas separation processes [2-5] due to high molecular sieve-like selectivities, and high stability at enhanced temperatures and in chemically aggressive atmospheres (compared with polymeric membranes). Also, the application of ceramic membranes in so-called membrane reactors, using catalytically active or passive membranes, has proven to be very promising and an increasing research effort in this field is observed in the past

* Corresponding author. few years [6-11]. The development of membrane reactors can be seen as a spin-off of ceramic membrane research and looks to evolute to a new class of unit operations in chemical engineering due to the integration of catalysis, membrane science and chemical reactor design in a completely new concept.

As shown in model studies of Zaspalis and co-workers $[12,13]$, the incorporation of microporous membranes in these membrane reactor systems can be very advantageous. If conditions are chosen correctly, high membrane selectivities (e.g. for $\mathrm{H}_{2}$ in the case of dehydrogenation reactions) allow the achievement of high equilibria shifts (e.g. by factors $>7-8$ ), while the high permeabilities allow operation at industrially attractive 
conditions. An important conclusion from this study is that the application of highly separative membranes with very low permeation rates (e.g. palladium membranes with infinite separation factors for $\mathrm{H}_{2}$ ) does not improve the reactor performance unless very slow reactions are used. Membrane systems with the combination of moderate separation factors in the order of 100 with high permeation rates, however, proved to be very effective for enhancement of the reactor performance.

Sol-gel modification of mesoporous $(1 \mathrm{~nm}<$ $r_{\text {pore }}<25 \mathrm{~nm}$ [1]) membranes with polymeric silica sols has proven to be a very successful process for the preparation of microporous membranes [14-20]. Due to the very thin top-layers, ca. $50-100 \mathrm{~nm}$, the gas permeation rates through these membranes are relatively high. Gas separation factors are typically on the order of 100-200 ( $\mathrm{H}_{2}$-propene, $\left.\mathrm{H}_{2}-\mathrm{CH}_{4}[14,16,17], \mathrm{He}-\mathrm{N}_{2}[15]\right)$. The combination of high permeation with high separation factors makes these membrane systems attractive candidates for application in membrane reactors. However, the stability of sol-gel derived silica looks to be a disadvantage. Due to aging, especially at higher temperatures in the presence of water, densification can take place [20-23].

An alternative technique for the preparation of microporous membranes is modification of mesoporous glass or ceramic membranes by CVD techniques [22-29]. This can result in very high separation factors ranging from $1000\left(\mathrm{He}-\mathrm{N}_{2}\right.$ [26]) to $>3000\left(\mathrm{H}_{2}-\mathrm{N}_{2}\right.$ [22] $)$. The permeation rates, however, are generally a factor 100 lower than for the sol-gel modified derived microporous membranes.

Leaching of the borosilicate component of hollow glass fibers, prepared by attenuation from glass melts, can also successfully result in the formation of a microporous structure [30,31]. The gas permeation rates are comparable with sol-gel derived systems. However, contrary to sol-gel derived membranes, the selectivity decreases as the temperature is increased [31]. For example, the separation factor for $\mathrm{He}-\mathrm{CH}_{4}$ at $30^{\circ} \mathrm{C}$ is 11674 , while it is decreased to 261 at $250^{\circ} \mathrm{C}$.

The interest for zeolite membranes strongly increased in recent years. Advantages of these systems are the very narrow pore size distribution (in fact there is only a single crystallographic pore size) and the generally higher chemical stability. A review of this field is given by Burggraaf et al. [4]. The formation of defect-free zeolite membranes, however, proved to be extremely difficult, and only recently the first results of zeolite membranes have been reported by Geus and co-workers [32-34]. Continuous MFI layers with a thickness of $50 \mu \mathrm{m}$ were grown randomly oriented on a porous sintered stainless-steel support. The highest selectivity was found for a butane-methane mixture at $300 \mathrm{~K}$, with a separation factor of 380 and butane as the fastest permeating component. Butane is strongly adsorbed in the zeolite layer, resulting in a decreased methane flux. The separation decreases with decreasing temperature due to decreased butane adsorption. At higher temperatures, where sorption follows Henry's law, the selectivity is based on the permeability ratio of the pure gas components.

Comparable results have now been reported by Jia et al. [35], and present work by Vroon et al. [36] resulted in thin supported MFI membranes on $\alpha$-alumina supports, with a thickness much smaller than that reported by Bakker and coworkers [32-34] and with improved properties.

The objective of this paper is to present an extensive overview of results from permeation experiments with single gases and from separation experiments with binary gas mixtures through microporous silica-modified ceramic membranes.

These membranes were obtained by a sol-gel modification technique as described earlier $[16,17,19,20]$. Polymeric silica sols were prepared by acid catalysis of tetraethylorthosilicate (TEOS). Analysis of the sols with SAXS showed that the fractal dimensions were typically on the order of 1.5 and radii of gyration were ca. $30 \AA[19,20,37]$. Non-supported membranes prepared from these sols were found to be $100 \%$ microporous, as determined with $\mathrm{N}_{2}$ adsorption. The porosity was typically $30-40 \%$, and the pore size distribution was bimodal with a strong maximum at an effective pore diameter of around $0.5 \mathrm{~nm}$ and a weaker maximum at $0.75 \mathrm{~nm}[19,20,38]$. Dip-coating of $\gamma$-alumina membranes with diluted sols resulted in deposition of ultra-thin microporous top-layers, with a thickness of around $100 \mathrm{~nm}$ [17]. 
Since hydrogen separation is a commercially interesting component in separation as well as in membrane reactor applications (dehydrogenation), the separation experiments were focused on hydrogen. An important point of attention is the relation between membrane quality and gas transport properties. Further, the correlation between molecular size, activation energy and relative permeation rates is shown clearly.

The results reported in the present paper belong to a systematic investigation to study the gas transport mechanism of the microporous sol-gel derived ceramic membranes and to evaluate their prospects for gas separation processes [20]. Results from sorption experiments with different gases on non-supported silica membranes and integration of the experimental results with the theory of gas transport through microporous membranes will be presented elsewhere $[20,39,40]$.

\section{Theory}

\subsection{Gas transport in microporous membranes}

Phenomenologically it has been found that the flux $J\left(\mathrm{~mol} \mathrm{~m}^{-2} \mathrm{~s}^{-1}\right)$ through microporous materials (zeolites, microporous carbons, glass and amorphous systems) increases as a function of temperature according to

$J \propto J_{0} \exp \left(\frac{-E_{\text {act }}}{R T}\right)$

where $E_{\text {act }}\left(\mathrm{kJ} \mathrm{mol}^{-1}\right)$ is the activation energy. Depending on micropore size and gas molecule size, activation energies ranging from around 2 to $40 \mathrm{~kJ} \mathrm{~mol}^{-1}$ have been reported [14-17,41,42].

This activation energy, however, is an apparent one, since it can be regarded to consist of a contribution of the activation energy for micropore diffusion $\left(E_{1}\right)$ and a contribution of the isosteric heat of adsorption $\left(q^{\text {st }}\right)$ of the gas molecules on the membrane surface ${ }^{1}$. An extensive model

\footnotetext{
${ }^{1}$ In addition, the directly measured permeation for composite membranes, consisting of a microporous top-layer on a mesoporous support, has first to be corrected for the flow resistance over the support in order to calculate the true permeation of the microporous top-layer only.
}

description, which is among others based on a theoretical model for gas transport in microporous zeolite crystals, with a fixed pore size as proposed by Barrer [43] is given elsewhere [40]. A brief summary is given below.

The intracrystalline flux through a zeolite crystal or microporous membrane can be given by [43]

$J=\frac{s k_{1}}{n-1} \exp \left(\frac{-E_{1}}{R T}\right)\left[\theta_{1}-\theta_{n}\right]$

where $s$ is the number of pores per cross-section area $\left(\mathrm{m}^{-2}\right)$ normal to the direction of $J, n$ is the number of diffusion steps in the pore, $\theta_{1}$ is the occupation degree $\left[\theta=n / n_{\infty}\right.$ where $n$ is the amount adsorbed $\left(\mathrm{mol} \mathrm{kg}^{-1}\right)$ at a certain pressure and $n_{\infty}$ is the amount adsorbed at saturation] at the pore entrance, and $\theta_{n}$ is the occupation degree at the end of the pore. The rate constant for jumping across energy barriers within the crystal (micropore diffusion), $k$, is given by

$k=k_{1} \exp \left(\frac{-E_{1}}{R T}\right)$

where $k_{1}$ is the pre-exponential constant and $E_{1}$ is the activation energy. If sorption obeys Henry's law, the occupation degree can be expressed as

$\theta=\frac{1}{n_{\infty}} K P$

where $K$ is Henry's constant $\left(\mathrm{mol} \mathrm{kg}^{-1} \mathrm{~Pa}^{-1}\right)$ and $P$ is the pressure ( $\mathrm{Pa})$. The temperature dependence of the Henry's constant can be described by:

$K=K_{0} \exp \left(\frac{q^{\mathrm{st}}}{R T}\right)$

where $K_{0}$ is a pre-exponential constant.

Substitution of Eqs. 3, 4 and 5 in Eq. 2 shows that for the given conditions (Henry sorption) the flux is linearly dependent on the pressure difference, and the apparent activation energy $E_{\text {act }}$ is a summation of $E_{1}$ and $-q^{\text {st }}$.

However, since $\theta_{1}$ and $\theta_{n}$ are steady-state fractions rather than equilibrium ones, the interface processes have to be analyzed in order to describe the deviation from equilibrium. If interface processes become rate-limiting, the simple analysis as 
shown here cannot be used without corrections; this will be described in greater detail in our extensive analysis of gas transport [20,39].

It is clear that for a complete analysis of the gas transport mechanism of the microporous membranes, both transport and sorption measurements have to be performed and integrated.

\subsection{Gas transport in mesoporous membranes}

Several gas transport mechanisms may be important in mesoporous materials: (i) Knudsen diffusion, (ii) laminar (or Poiseuille) flow and (iii) surface diffusion. These components to gas transport are expressed as follows $[44,45]$.

\section{Knudsen diffusion}

$F_{\mathrm{Kn}, 0}=\frac{2 \varepsilon_{\mathrm{p}} \mu_{\mathrm{Kn}} \bar{v} \bar{r}}{3 R T L}, \quad \bar{v}=\sqrt{\frac{8 R T}{\pi M}}$

where $F_{\mathrm{Kn}, 0}$ is the Knudsen permeation ( $\mathrm{mol} \mathrm{m}^{-2}$ $\left.\mathrm{s}^{-1} \mathrm{~Pa}^{-1}\right), \varepsilon_{\mathrm{p}}$ is the porosity $(-), \mu_{\mathrm{Kn}}$ is a shape factor (-) equal to $1 / \tau$, where $\tau$ is the tortuosity, $R$ is the gas constant $\left(\mathrm{J} \mathrm{mol}^{-1} \mathrm{~K}^{-1}\right), T$ is the absolute temperature $(\mathrm{K}), \bar{r}$ is the model pore radius $(\mathrm{m}), \bar{v}$ is the average molecular velocity $\left(\mathrm{m} \mathrm{s}^{-1}\right), L$ is the layer thickness (m), and $M$ is the molecular mass $\left(\mathrm{kg} \mathrm{mol}^{-1}\right)$ of a gas molecule.

Laminar flow

$F_{\mathrm{P}, 0}=\frac{\varepsilon_{\mathrm{p}} \mu_{\mathrm{P}} \bar{r}^{2}}{8 R T \eta L} P_{\mathrm{m}}$

where $F_{\mathrm{P}, 0}$ is the Poiseuille permeation ( $\mathrm{mol} \mathrm{m}^{-2}$ $\left.\mathrm{s}^{-1} \mathrm{~Pa}^{-1}\right), \mu_{\mathrm{p}}$ is the reciprocal tortuosity $(-), \eta$ is the gas viscosity $\left(\mathrm{N} \mathrm{s} \mathrm{m}^{-2}\right), L$ is the thickness (m) of the porous layer, and $P_{\mathrm{m}}$ is the mean pressure $(\mathrm{Pa})$.

\section{Surface diffusion}

$J_{\mathrm{s}, 0}=-\rho_{\mathrm{app}} \mathrm{D}_{\mathrm{s}} \mu_{\mathrm{s}} \frac{\mathrm{d} q}{\mathrm{~d} l}$

where $J_{\text {s.o }}$ is the surface diffusion flux component $\left(\mathrm{mol} \mathrm{m}{ }^{-2} \mathrm{~s}^{-1}\right), \rho_{\text {app }}$ is the apparent density $\left(\mathrm{kg} \mathrm{m}^{-3}\right)$, defined as $\left(1-\varepsilon_{\mathrm{p}}\right) \rho_{\text {cryst }}, D_{\mathrm{S}}$ is the surface diffusion coefficient $\left(\mathrm{m}^{2} \mathrm{~s}^{-1}\right), \mu_{\mathrm{s}}$ is the reciprocal tortuosity $(-)$ and $\mathrm{d} q / \mathrm{d} l$ the surface concentration gradient $\left(\mathrm{mol} \mathrm{kg} \mathrm{kg}^{-1} \mathrm{~m}^{-1}\right)$. The activation energy for diffusion is strongly correlated to the heat of adsorption. Since it is assumed that diffusion takes place by molecules which jump from one site to another, the activation energy is a fraction of the heat of adsorption [46]. This implies that (i) strongly adsorbed molecules are less mobile than weakly adsorbed molecules and (ii) the total flux will decrease with decreasing temperature since the increased diffusivity is overruled by the decrease in surface concentration.

At low temperatures and high pressures, additional transport mechanisms are multi-layer diffusion and capillary condensation. The permeability of strongly adsorbing gases can be improved by a factor 6 compared with Knudsen diffusion at relative vapor pressures of $0.4-0.8$, as has been shown by Uhlhorn et al. [47] for magnesia-modified $\gamma$-alumina membranes. A maximum in permeability occurs at the point where pore blocking takes place (capillary condensation).

Transport of multi-component mixtures in porous media according to the combined mechanisms as described before can be analyzed by the so-called dusty gas model, where the diffusivities are expressed according to the Maxwell-Stefan theory. An extended discussion of this approach can be found elsewhere $[45,48]$.

For the mesoporous $\gamma$-alumina membranes prepared in our laboratory, which are used in the present study as a support for the microporous top-layer, Knudsen diffusion prevails for the gases and conditions used in this study $\left(T>20^{\circ} \mathrm{C}\right.$, $0<P<5$ bar) $[47,49]$.

\section{Experimental}

\subsection{Supported membrane formation}

$\gamma$-Alumina membranes were prepared by a dipcoating process of $\alpha$-alumina supports (disc shape, $39 \mathrm{~mm}$ diameter, $2 \mathrm{~mm}$ thick, $160 \mathrm{~nm}$ mean pore radius, $50 \%$ porosity, around $40 \mathrm{~nm}$ surface roughness) in boehmite $(\gamma$-AlOOH) dip solutions, as described previously $[17,50,51]$. The membranes were dried in a climate chamber for $3 \mathrm{~h}\left(40^{\circ} \mathrm{C}\right.$, $60 \%$ R.H.) prior to calcination in static air for $3 \mathrm{~h}$ 
at $600^{\circ} \mathrm{C}$ (heating and cooling rate $60^{\circ} \mathrm{C} / \mathrm{h}$ ). Depending on membrane quality, this procedure was repeated one or two times to obtain a defectfree membrane; the final top-layer thickness was on the order of $7-10 \mu \mathrm{m}$, with a mean pore diameter of around $5 \mathrm{~nm}$.

These membranes were modified with polymeric silica sols to obtain a microporous top-layer. Polymeric $\mathrm{SiO}_{2}$ sols were prepared by acidcatalyzed hydrolysis of TEOS in ethanol with TEOS/water $/ \mathrm{HNO}_{3} /$ ethanol standard molar ratios of $1: 6.4: 0.085: 3.8$ (sample code $\mathrm{StSiO}_{2}$ ). The sols were prepared by careful addition of water and acid to the TEOS-ethanol solution, followed by $3 \mathrm{~h}$ of refluxing at $80^{\circ} \mathrm{C}$ under stirring. $\gamma$-Alumina membranes were modified by a dip-coating process using $18 \times$ ethanol-diluted $\mathrm{SiO}_{2}$ sols. Calcination of the membranes was performed under static air for $3 \mathrm{~h}$ at $400^{\circ} \mathrm{C}$ (heating and cooling rate $25^{\circ} \mathrm{C} / \mathrm{h}$ ).

In some cases a second modification step was performed, or modified sol compositions, including binary $\mathrm{SiO}_{2}-\mathrm{TiO}_{2}, \mathrm{SiO}_{2}-\mathrm{Al}_{2} \mathrm{O}_{3}$ and $\mathrm{SiO}_{2}-\mathrm{ZrO}_{2}$ systems, were used. The dip solution used for the second silica modification was ten times more diluted than the standard dip solutions (total dilution of the sol:180 $x$ ). A more detailed description of the sol synthesis and membrane formation is given elsewhere $[17,20,37]$.

The codes for the membranes used are given as in Table 1 and are based on the number of membrane ( $\gamma$-alumina as well as microporous) layers.

\subsection{Permeation experiments}

Gas permeation experiments were performed by dead-end permeation measurements. The disc-

Table 1

Membrane codes

\begin{tabular}{llll}
\hline $\begin{array}{l}\text { Membrane } \\
\text { code }\end{array}$ & $\begin{array}{l}\text { Number of } \\
\gamma \text {-alumina } \\
\text { layers }\end{array}$ & $\begin{array}{l}\text { Number of } \\
\text { microporous } \\
\text { layers }\end{array}$ & $\begin{array}{l}\text { Remark } \\
\text { top layer }\end{array}$ \\
\hline Al1-Sil & 1 & 1 & $\mathrm{SiO}_{2}$ \\
A13-Si1 & 3 & 1 & $\mathrm{SiO}_{2}$ \\
A13-Si2 & 3 & 2 & $\mathrm{SiO}_{2}$ \\
A13-SiTi & 3 & 1 & $\mathrm{SiO}_{2} / \mathrm{TiO}_{2}$ \\
A13-SiAl & 3 & 1 & $\mathrm{SiO}_{2} / \mathrm{Al}_{2} \mathrm{O}_{3}$ \\
\hline
\end{tabular}

shaped membranes were placed in stainless-steel cells (Velterop R 250), using Kalrez (DuPont) sealings, with the microporous top-layer at the feed side. The permeation area was $1.911 \mathrm{~cm}^{2}$, and the maximum process temperature was $300^{\circ} \mathrm{C}$.

The gas flow $\left(\mathrm{ml} \mathrm{min}^{-1}\right)$ through the membrane was controlled by mass flow controllers (MFCs, Brooks 5051) with maximum flow ranges of 200, 20 and $5 \mathrm{ml} \mathrm{min}^{-1}$, which were placed parallel. Depending on the permeation rate for a certain system, the controller with the most accurate range was selected. The feed pressure and pressure difference over the membrane were measured using pressure transducers (Validyne). The low pressure side of the membrane was evacuated $(P \approx 0.01 \mathrm{bar})$. A schematic presentation is shown in Fig. 1.

Microporous membranes were degassed prior to the permeation measurements, in order to remove adsorbed water from the micropores, by overnight heating to $200^{\circ} \mathrm{C}\left(60^{\circ} \mathrm{C} / \mathrm{h}\right.$ heating and cooling rate) with a hydrogen flow of $1 \mathrm{ml} \mathrm{min}^{-1}$ and the low pressure side connected to the vacuum pump. The used gases were $>99.9 \%$ pure (isobutane $99.5 \%$ ).

The permeation $(F)^{1}$ is defined as the ratio of the transmission rate or flux (quantity of gas crossing a unit area in unit time; in mol $\mathrm{m}^{-2} \mathrm{~s}^{-1}$ ) and the (partial) pressure difference [52] in mol m $\mathrm{m}^{-2} \mathrm{~s}^{-1} \mathrm{~Pa}^{-1} \quad\left(\equiv 1.344 \cdot 10^{7} \mathrm{ml} \mathrm{min}^{-1} \mathrm{~cm}^{-2}\right.$ $\left.\operatorname{bar}^{-1} \equiv 1.93 \cdot 10^{8} \mathrm{~m}^{3} \quad \mathrm{~m}^{-2} \mathrm{day}^{-1} \quad \mathrm{bar}^{-1}\right)$. The

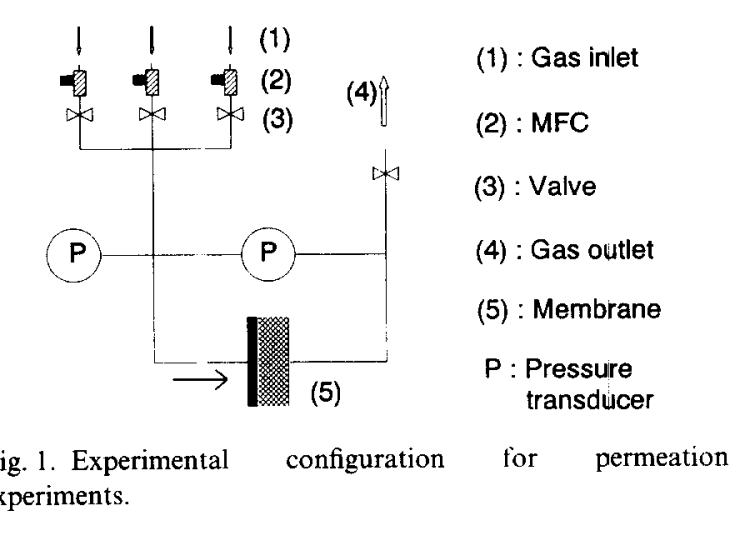

\footnotetext{
${ }^{1}$ The permeation implicitly contains the layer thickness $(l)$ of the membrane, and is therefore not a real material constant. The so-called permeability, defined as the product $F l$ in units mol $\mathrm{m} \mathrm{m}^{-2} \mathrm{~s}^{-1} \mathrm{~Pa}^{-1}$ [52], corrects for layer thickness ( provided it is known accurately). Unfortunately the meaning of permeation and permeability is often confused in the literature.
} 
apparent activation energy for permeation is calculated according to Eq. 1 .

Corrections for the support ( $=\gamma$-alumina membrane $=\alpha$-alumina substrate $+\gamma$-alumina top-layer $)$ influence on the permeation of the microporous top-layer have to be performed to calculate the real pressure drop over the microporous top-layer. These corrections were performed by the series model [45,53], which requires knowledge of the permeation characteristics of the support. An extensive description of the calculation method and influence on the calculated permeation rates is given elsewhere [17].

Unless stated otherwise, non-corrected permeation data will be given first to show the actual performance of the membrane system ( $\equiv$ microporous sol-gel modified $\gamma$-alumina membrane). For the analysis of the gas transport mechanism, corrected data will be used.

The relative accuracy in the calculated permeation rates and apparent activation energy is in the order of $5 \%$.

\subsection{Separation experiments}

Counter-current separation experiments are performed at temperatures ranging from 25 to $300^{\circ} \mathrm{C}$. The equipment used has been previously described, where for the separation experiments stainless-steel cells were used with two gas inlets (for the feed and the purge gas) and two gas outlets. Argon purge gas was used at the permeate side with a standard flow of $150 \mathrm{ml} \mathrm{min}-1$. The outlet at the permeate side was connected to a high-vacuum pump (Edwards). Both the retentate and the permeate composition were analyzed using a gas chromatograph (Varian 3300). A schematic presentation is shown in Fig. 2.

The ideal separation factor $(\alpha)$ is defined as the enrichment factor of one component in the permeate compared to the feed composition according to:

$\alpha=\frac{y}{1-y} \frac{1-x}{x}$

where $y$ is the molar fraction of the faster permeating component in the permeate and $x$ is the molar

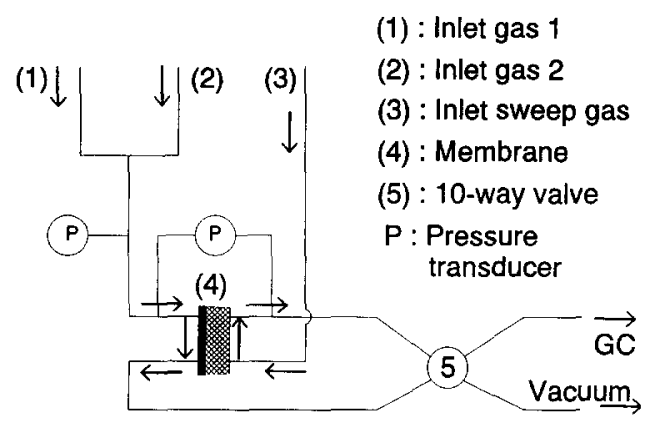

Fig. 2. Experimental configuration (counter-current mode) for separation experiments.

fraction of this component in the feed. Deviations from ideality can be caused by back-diffusion, concentration polarization, Poiseuille flow in larger pores and concentration polarization at the feed and/or permeate side [49]. Back-diffusion can take place when $P_{\text {low }} \neq 0$; this can be avoided by introducing vacuum at the low pressure side, or by using a sweep gas resulting in a decrease of the partial pressure of the permeants.

Microporous membranes were degassed prior to the separation measurements, in order to remove adsorbed water from the micropores, by overnight heating to $200^{\circ} \mathrm{C}$ with a hydrogen flow of $1 \mathrm{ml}$ $\min ^{-1}$ and the low pressure side connected to the vacuum pump.

\section{Results}

\subsection{Permeation results of membrane Al3-Sil-I}

Membrane Al3-Sil-I consist of standard, three times dipped $\gamma$-alumina mesoporous membranes, which have been modified in a single dipping step with freshly prepared standard polymeric silica sols. In Figs. 3 and 4 the measured $\mathrm{H}_{2}$ and $\mathrm{CO}_{2}$ flows (in ml $\min ^{-1}$ ) of membrane Al3-Sil-I are given as function of feed pressure. As can be seen from Fig. 3, the $\mathrm{H}_{2}$ flow is, within the experimental error, linearly dependent on the feed pressure, which means that the permeation (in $\mathrm{mol} \mathrm{m}^{-2}$ $\mathrm{s}^{-1} \mathrm{~Pa}^{-1}$ ) is pressure-independent. For $\mathrm{CO}_{2}$ it can be seen in Fig. 4 that the flow is linearly dependent on feed pressure for 100 and $200^{\circ} \mathrm{C}$. At $28^{\circ} \mathrm{C}$, 


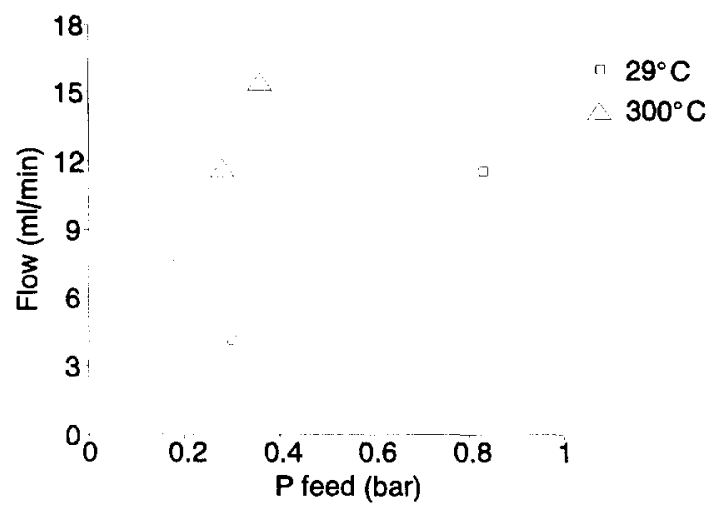

Fig. 3. Hydrogen flow for silica-modified membrane Al3-Si1-A.

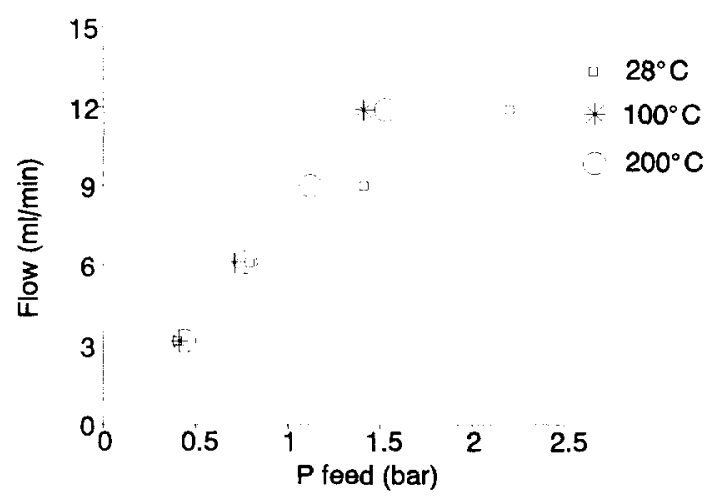

Fig. 4. $\mathrm{CO}_{2}$ flow for silica-modified membrane Al3-Sil-A.

however, a slight deviation from linearity can be seen. This can be explained by the non-Henry adsorption behavior of $\mathrm{CO}_{2}$ at this low temperature. The surface concentration does not increase linearly with pressure, and can be described as a Langmuir isotherm, as shown in our sorption study $[40]$.

The gas permeation of the membranes ( $\equiv$ silica modified $\gamma$-alumina $+\alpha$-alumina support) is calculated by dividing the flow through the membrane by the product of measurement area $\left(1.911 \mathrm{~cm}^{2}\right)$ and pressure difference over the membrane. $\mathrm{H}_{2}$ and $\mathrm{CO}_{2}$ permeations for membrane Al3-Sil-I are shown in Figs. 5 and 6.

As can be seen from Fig. 5 , the $\mathrm{H}_{2}$ permeation is activated. This indicates that an effective modification towards micropore diffusion is obtained, since according to Knudsen diffusion the permeation should decrease with increasing temperature

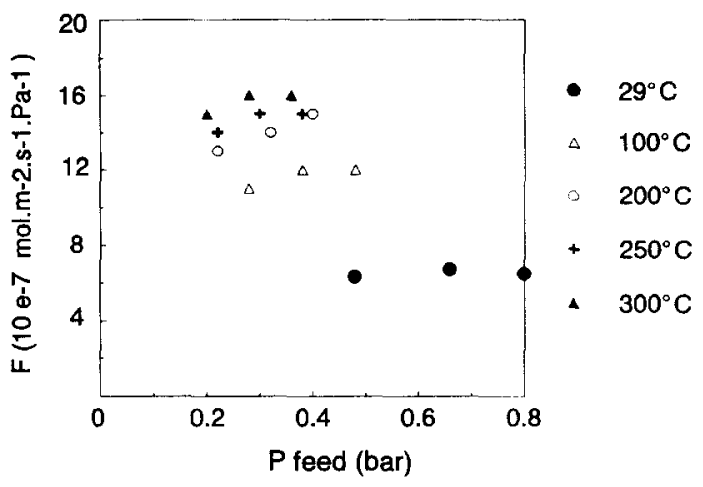

Fig. 5. Hydrogen permeation of silica-modified membrane Al3-Sil-A.

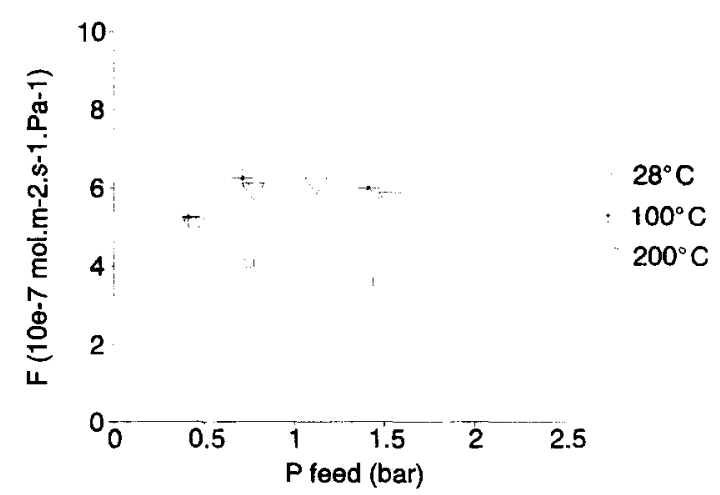

Fig. 6. Carbon dioxide permeation of silica-modified membrane Al3-Sil-A.

(Eq. 2). As has been shown previously [17], the permeation is generally pressure-independent to higher feed pressures up to 4 bar. In some cases, as for this membrane, however, it looks that at lower pressures $\left(P_{\text {high }}<0.5\right.$ bar $)$ the permeation slightly increases as a function of pressure, and results in a plateau at higher pressures. However, within the experimental error this deviation is small and may be determined by the lower accuracy of the pressure transducers at low pressures.

At $20^{\circ} \mathrm{C}$, the carbon dioxide permeation (Fig. 6) decreases with increasing pressure. This can be explained by analysis of Fig. 4, where it is shown that for this membrane at $28^{\circ} \mathrm{C}$ the $\mathrm{CO}_{2}$ flow is not linearly dependent on the pressure. At higher pressures, the incremental increase of the gas flow decreases, and, consequently, the permeation will decrease as a function of pressure in this range. 
For the higher temperatures, the permeation is, within the experimental error, pressureindependent.

Oxygen and nitrogen permeation results for

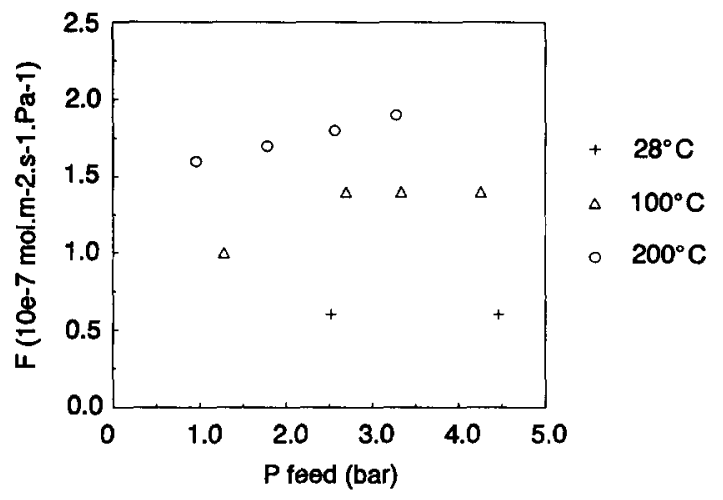

Fig. 7. Oxygen permeation of silica-modified membrane Al3-Si1-A.

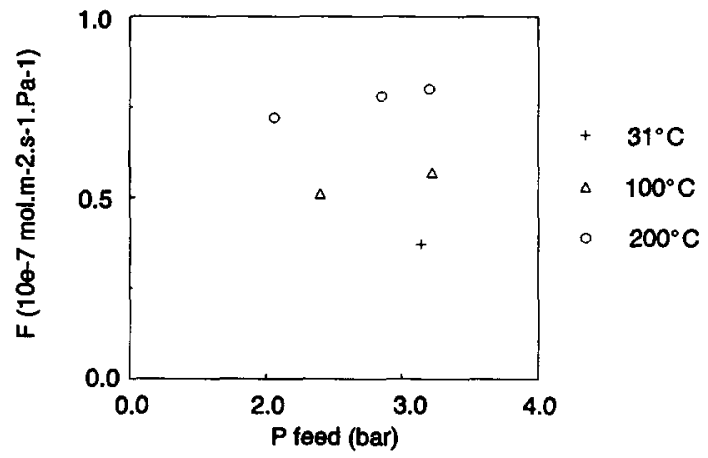

Fig. 8. Nitrogen permeation of silica-modified membrane Al3-Si1-A. membrane Al3-Sil-I are shown in Figs. 7 and 8 respectively. As can be seen, these gases show activated diffusion as well, indicating that the transport mechanism for these gases is modified. Also, the permeation rates for $\mathrm{O}_{2}$ are higher than for $\mathrm{N}_{2}$, contrary to transport according to the Knudsen diffusion mechanism.

Methane permeation was difficult to detect due to the very low permeation rates, which are on the order of the sensitivity limit of the equipment. Only two single points could be measured for comparison reasons; permeation values $(F)$ are $0.27 \cdot 10^{-7}$ and $0.36 \cdot 10^{-7} \mathrm{~mol} \mathrm{~m}^{-2} \mathrm{~s}^{-1} \mathrm{~Pa}^{-1}$ at 25 and $200^{\circ} \mathrm{C}$, respectively. Due to the very low permeation rates, the accuracy is low.

The results for membrane Al3-Si1-I have been summarized in Table 2. The permeation rates at 25 and $200^{\circ} \mathrm{C}$ and apparent activation energies are given with permselectivities (ratio of permeation rates) at these temperatures. Also, the values for the permeation after correction for the support ( $\equiv \gamma$-alumina membrane) resistance are given. This corrected permeation is calculated, as has been previously described extensively [17], using the real pressure difference over the microporous toplayer, $P_{\text {high }}-P_{\text {interface }}$ (where $P_{\text {interface }}$ is the pressure at the interface between the microporous top-layer and the $\gamma$-alumina membrane) instead of $P_{\text {high }}-P_{\text {low }}$. Therefore, the corrected permeation rates are higher.

Since the permeation of the support decreases as a function of temperature, which leads to an increased pressure drop over the support, the

Table 2

Permeation rates and apparent activation energies for silica-modified membrane A13-Si1-I

\begin{tabular}{|c|c|c|c|c|c|c|c|c|}
\hline \multirow[t]{4}{*}{ Gas } & \multirow{2}{*}{\multicolumn{3}{|c|}{$\begin{array}{l}\text { Permeation }^{\mathrm{a}} \\
\left(10^{-7} \mathrm{~mol} \mathrm{~m}^{-2} \mathrm{~s}^{-1} \mathrm{~Pa}^{-1}\right)\end{array}$}} & \multirow{4}{*}{$\begin{array}{l}\text { Apparent } \\
E_{\text {act }} \\
\left(\mathrm{kJ} \mathrm{mol}^{-1}\right)\end{array}$} & \multicolumn{4}{|c|}{ Permselectivity } \\
\hline & & & & & \multicolumn{2}{|c|}{ Non-corrected $\left(\mathrm{H}_{2}-\mathrm{X}\right)$} & \multicolumn{2}{|c|}{ Corrected $\left(\mathrm{H}_{2}-\mathrm{X}\right)$} \\
\hline & \multirow[t]{2}{*}{$25^{\circ} \mathrm{C}$} & \multirow{2}{*}{\multicolumn{2}{|c|}{$200^{\circ} \mathrm{C}$}} & & & & & \\
\hline & & & & & $25^{\circ} \mathrm{C}$ & $200^{\circ} \mathrm{C}$ & $25^{\circ} \mathrm{C}$ & $200^{\circ} \mathrm{C}$ \\
\hline $\mathrm{H}_{2}$ & $6.5 \quad(6.8)$ & 16 & $(28.6)$ & $5.0(7.4)$ & - & - & - & - \\
\hline $\mathrm{CO}_{2}$ & $2.5 \quad(3.6)$ & 3 & $(5.7)$ & $-(-)$ & 2.6 & 5.3 & 1.9 & 5.0 \\
\hline $\mathrm{O}_{2}$ & $0.6 \quad(0.64)$ & 1.7 & $(2.5)$ & $7.0(8.4)$ & 10.8 & 9.4 & 10.6 & 11.4 \\
\hline $\mathrm{N}_{2}$ & $0.37(0.38)$ & 0.8 & $(0.9)$ & $5.0(5.5)$ & 18.6 & 22.9 & 17.9 & 31.8 \\
\hline $\mathrm{CH}_{4}$ & $0.27(0.28)$ & 0.36 & $(0.37)$ & $1.7(1.8)$ & 23.2 & 43.2 & 24.3 & 77.3 \\
\hline
\end{tabular}

a Values between parentheses are corrected for support influence. 
correction is stronger at higher temperatures. For example, for $\mathrm{H}_{2}$ the support resistance is only $4 \%$ at $25^{\circ} \mathrm{C}$, while it is $44 \%$ at $200^{\circ} \mathrm{C}$. Therefore, support correction results in an increased apparent activation energy. This is shown in Fig. 9, where the Arrhenius plot of the hydrogen permeation is given. The Arrhenius plot for the corrected data is, within the experimental error, a straight line.

Also, the support correction is less strong if the permeation of the total system is low compared to the permeation of the support. This is for example the case for the low-temperature data for hydrogen, and the data for $\mathrm{N}_{2}$ and $\mathrm{CH}_{4}$. The relative resistance for gas permeation of the toplayer is then large.

As can be clearly seen the permeation rates decrease as a function of the kinetic diameter: $\mathrm{H}_{2}>\mathrm{CO}_{2}>\mathrm{O}_{2}>\mathrm{N}_{2}>\mathrm{CH}_{4}$ (Table 3) [54]. The permselectivity, given for both the membrane and the top-layer, increases as a function of temperature for all given combinations, except for $\mathrm{H}_{2}-\mathrm{O}_{2}$ where a slight decrease can be seen. Since the activation energy for hydrogen permeation is higher than for the other gas, for all combinations except $\mathrm{H}_{2}-\mathrm{O}_{2}$, the permselectivity increases as a function of temperature. The absolute values for the permselectivities are high compared with those based on Knudsen diffusion (note: $\alpha_{\mathrm{A} / \mathbf{B}}$. Knudsen $=$ $\left.F_{\mathrm{A}} / F_{\mathrm{B}}=\left(M_{\mathrm{B}} / M_{\mathrm{A}}\right)^{0.5}\right)$, e.g. $\quad \alpha_{\mathrm{H}_{2} / \mathrm{CH}_{4}, \text { Knudsen }}=2.83$. Also, it can be seen that the top-layer permselectiv-

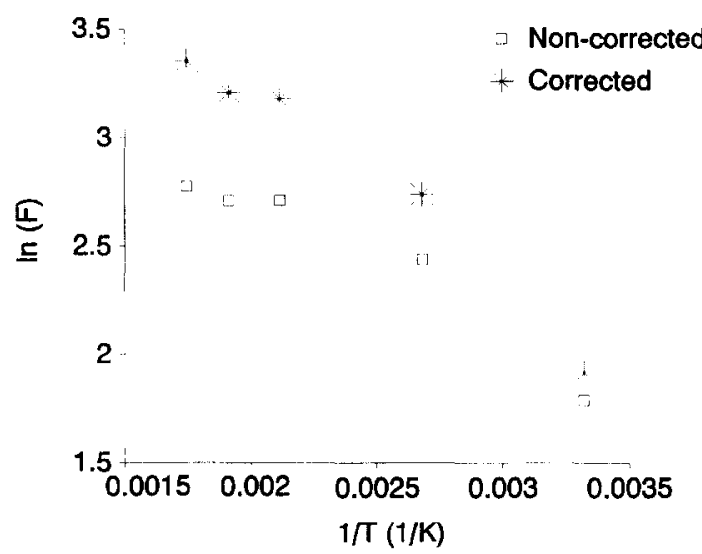

Fig. 9. Arrhenius plot of hydrogen permeation for silicamodified membrane Al3-Sil-A. $F$ in $10^{-7} \mathrm{~mol} \mathrm{~m}^{-2} \mathrm{~s}^{-1} \mathrm{~Pa}^{-1}$. Data taken at $P_{\text {high }}=0.4$ bar.
Table 3

Kinetic diameters for some selected gases, according to Ref. [54]

\begin{tabular}{ll}
\hline $\mathrm{Gas}$ & Kinetic diameter $\sigma(\mathrm{nm})$ \\
\hline $\mathrm{He}$ & 0.26 \\
$\mathrm{H}_{2} \mathrm{O}$ & 0.265 \\
$\mathrm{H}_{2}$ & 0.289 \\
$\mathrm{CO}_{2}$ & 0.33 \\
$\mathrm{O}_{2}$ & 0.346 \\
$\mathrm{~N}_{2}$ & 0.364 \\
$\mathrm{CH}_{4}$ & 0.38 \\
$\mathrm{C}_{3} \mathrm{H}_{8}$ & 0.43 \\
Isobutane & 0.5 \\
$\mathrm{Benzene}_{\mathrm{CCl}}$ & 0.585 \\
\hline
\end{tabular}

ity is much better than that for the total membrane system. These differences are higher for the data at $200^{\circ} \mathrm{C}$, since in these cases the support correction is larger than for the data at $25^{\circ} \mathrm{C}$ due to the higher support resistance at higher temperature. The consequence is that one should strive for supports with relatively low flow resistances.

\subsection{Permeation results of silica-modified membrane All-Sil-A}

The main goal to investigate modified membranes with only one $\gamma$-alumina layer is to evaluate the effect of possible defects of the supporting membranes on the final quality of the modified membranes. Further, it is of technological and economical interest to reduce the total number of processing steps.

In Fig. 10, the $\mathrm{H}_{2}$ permeation is shown. It can be seen that. generally, the temperature dependence for $\mathrm{H}_{2}$ is comparable with that of Al3-Sil-I (Fig. 5), but the absolute permeation rates are higher. The methane permeation (Fig. 11) increases continuously as a function of temperature; the permeation rates, however, are very low.

For this membrane, both the $\mathrm{CO}_{2}, \mathrm{O}_{2}$ and isobutane permeations decrease as a function of temperature. For isobutane (Fig. 12) it can also be seen that the permeation decreases slightly with pressure.

The results are summarized in Table 4, together with the calculated activation energies for permeation and permselectivities. Comparison with mem- 


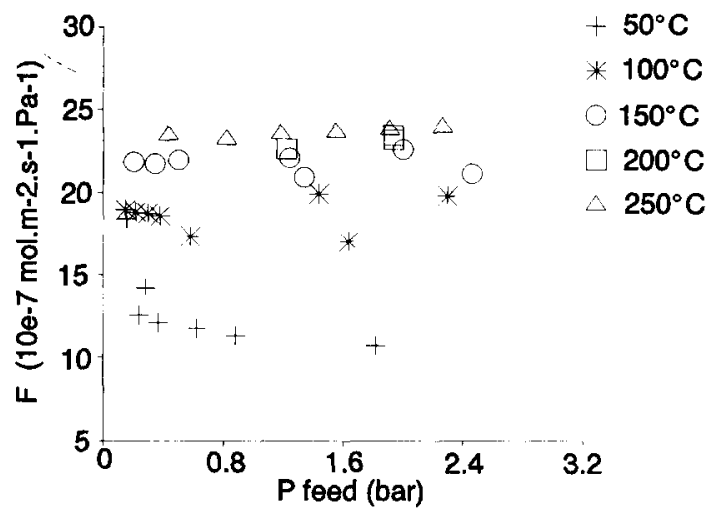

Fig. 10. Hydrogen permeation of silica-modified membrane Al1-Si1-A.

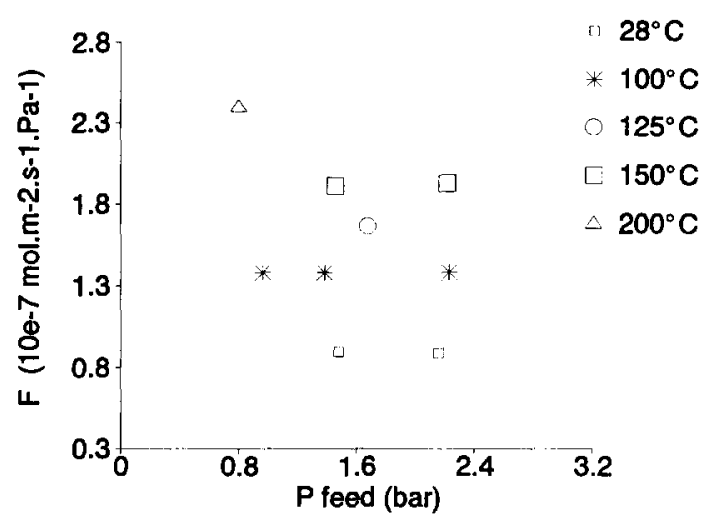

Fig. 11. Methane permeation of silica-modified membrane All-Sil-A.

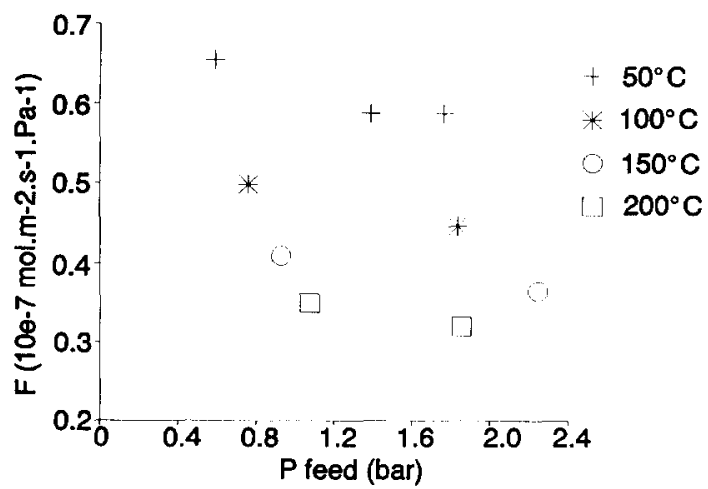

Fig. 12. Isobutane permeation of silica-modified membrane Al1-Si1-A. brane Al3-Sil-I shows that the apparent activation energy of the top-layer for hydrogen is higher, which results in increased permselectivities. The difference in methane and oxygen permeation behavior, however, for these two membranes is remarkable. For Al3-Sil-I the oxygen permeation is higher than the methane permeation, which looks like molecular sieving, but the activation energy for methane is lower. For membrane Al1-Si1-A the activation energy for oxygen is absent and the permeation rate is even higher than for $\mathrm{CO}_{2}$. The explanation for these results, related with defects in the top-layer, will be discussed in the next paragraph which summarizes the trends in permeation behavior.

\subsection{Summary of the most important permeation results of silica-modified membranes}

In Table 5 permeation results are summarized for silica-modified membranes (A13-Si1) with different activation energies for hydrogen. The apparent activation energies for the permeation of hydrogen (non-corrected as well as corrected for support influence) is given as main characteristic. For each of these membranes the permeation values at $200^{\circ} \mathrm{C}$ are given for several gases. The temperature of $200^{\circ} \mathrm{C}$ is chosen since the apparent activation energy can then be regarded as an integrated effect of the isosteric heat of adsorption and micropore diffusion, where effects of internal diffusion dominate at high temperature. At low temperatures, strong (non-Henry) sorption effects may be present, which can influence the transport mechanism strongly due to possible ratedetermining interface processes and/or pore blocking. As has been observed previously the general trend in Table 5, with an exception for membranes $\mathrm{Al} 3-\mathrm{Sil}-\mathrm{E}$, is that the permeation rate decreases continuously as a function of the gas molecular size.

For hydrogen, the corrected apparent activation energies varies from 5.8 to $21.7 \mathrm{~kJ} \mathrm{~mol}^{-1}$. Carbon dioxide permeation shows activated transport for membranes characterized by a hydrogen activation energy higher than ca. $10 \mathrm{~kJ} \mathrm{~mol}^{-1}$ (corrected value). The variation in activation energies for a certain gas is considered to be caused by differences 
Table 4

Permeation rates and apparent activation energies for silica-modified membrane All-Sil-A

\begin{tabular}{|c|c|c|c|c|c|c|c|c|c|}
\hline \multirow[t]{3}{*}{ Gas } & \multirow{2}{*}{\multicolumn{4}{|c|}{$\begin{array}{l}\text { Permeation } \\
\left(10^{-7} \mathrm{~mol} \mathrm{~m}^{-2} \mathrm{~s}^{-1} \mathrm{~Pa}^{-1}\right)\end{array}$}} & \multirow{3}{*}{$\begin{array}{l}\text { Apparent } \\
E_{\text {act }} \\
\left(\mathrm{kJ} \mathrm{mol}^{-1}\right)\end{array}$} & \multicolumn{4}{|c|}{ Permselectivity } \\
\hline & & & & & & \multicolumn{2}{|c|}{ Non-corrected $\left(\mathrm{H}_{2}-\mathrm{X}\right)$} & \multicolumn{2}{|c|}{ Corrected $\left(\mathrm{H}_{2}-\mathrm{X}\right)$} \\
\hline & \multicolumn{2}{|l|}{$50^{\circ} \mathrm{C}$} & \multicolumn{2}{|c|}{$200^{\circ} \mathrm{C}$} & & $50^{\circ} \mathrm{C}$ & $200^{\circ} \mathrm{C}$ & $50 \mathrm{C}$ & $200^{\circ} \mathrm{C}$ \\
\hline $\mathrm{H}_{2}$ & 12 & $(17)$ & & $(74)$ & $5.4(11.1)$ & -- & - & & \\
\hline $\mathrm{CO}_{2}$ & 4.5 & $(10.0)$ & 5.2 & $(18.9)$ & $-{ }^{b}$ & 2.7 & 4.2 & 1.7 & 3.9 \\
\hline $\mathrm{O}_{2}$ & $\approx 6$ & $(\approx 20)$ & 5.8 & $(20.0)$ & $-\mathbf{b}$ & 2 & 3.8 & 0.85 & 3.7 \\
\hline $\mathrm{CH}_{4}$ & 0.9 & $(1.0)$ & 2.4 & $(3.0)$ & $6.7 \quad(7.9)$ & 12 & 9.2 & 17 & 24.7 \\
\hline Isobutane & 0.59 & $(0.64)$ & 0.3 & $(0.37)$ & $-\mathrm{b}$ & 20 & 73 & 26.6 & 200 \\
\hline
\end{tabular}

a Value between parentheses are corrected for support influence.

${ }^{b}$ Decreasing permeation, Arrhenius plot not meaningful.

Table 5

Permeation rates $F$ at $200^{\circ} \mathrm{C}$ for silica-modified membranes Al3-Si1-A to $-\mathrm{K}$ with different quality characterized by their apparent activation energies $\left(\mathrm{kJ} \mathrm{mol}^{-1}\right)$ for hydrogen

\begin{tabular}{|c|c|c|c|c|c|c|c|c|c|c|c|}
\hline \multirow[t]{2}{*}{ Gas } & \multicolumn{11}{|c|}{$F\left(10^{-7} \mathrm{~mol} \mathrm{~m}^{-2} \mathrm{~s}^{-1} \mathrm{~Pa}^{-1}\right)$} \\
\hline & $\begin{array}{l}\text { A } \\
(14.9,21.7)^{\mathrm{a}}\end{array}$ & $\begin{array}{l}\mathrm{B} \\
(13.2,16.9)\end{array}$ & $\begin{array}{l}\mathrm{C}^{\mathrm{b}} \\
(11,12.3)\end{array}$ & $\begin{array}{l}\mathrm{D} \\
(8.0,11.2)\end{array}$ & $\begin{array}{l}\mathbf{E}^{\mathbf{c}} \\
(7.4,10.0)\end{array}$ & $\begin{array}{l}\mathrm{F}^{\mathrm{c}} \\
(6.7,11.0)\end{array}$ & $\begin{array}{l}\mathrm{G} \\
(5.8,8.3)\end{array}$ & $\begin{array}{l}\mathrm{H}^{\mathrm{d}} \\
(5.4,11.0)\end{array}$ & $\begin{array}{l}\text { I } \\
(5.0,7.4)\end{array}$ & $\begin{array}{l}\mathrm{J} \\
(4.4,5.8)\end{array}$ & $\begin{array}{l}\mathrm{K} \\
(3.2,6.6)\end{array}$ \\
\hline $\mathrm{He}$ & & - & - & - & 14.4 & 20.0 & - & - & - & - & . \\
\hline $\mathrm{H}_{2}$ & 21.7 & 16.0 & 13.0 & 18.0 & 17.9 & 22.2 & 21.8 & 23 & 16 & 12.3 & 20.0 \\
\hline $\mathrm{CO}_{2}$ & 6.8 & 5.5 & 3.5 & 5.5 & 5.1 & $6.0^{\mathrm{e}}$ & - & 5.2 & 3.0 & - & $8.5^{\mathrm{e}}$ \\
\hline $\mathrm{O}_{2}$ & - & - & - & 4.0 & - & - & 5.9 & 5.8 & 1.7 & -- & - \\
\hline $\mathrm{N}_{2}$ & $\ldots$ & - & - & - & - & - & 4.7 & - & 0.8 & - & \\
\hline $\mathrm{CH}_{4}$ & & - & - & - & - & - & $\ldots$ & 2.4 & 0.36 & & \\
\hline Isobutane &.- & - & - & - & - & - & - & 0.35 & -- & & - \\
\hline
\end{tabular}

${ }^{a} E_{\text {act }}\left(\mathrm{H}_{2}\right)$; italic values corrected for support influence.

${ }^{b}$ Data taken from Ref. [17].

${ }^{\mathrm{c}}$ Data taken from Uhlhorn et al. [14].

${ }^{d}$ Membrane All-Sil-A.

e $100^{\circ} \mathrm{C}$

in membrane quality. When some defects (pinholes, cracks or wider micropores) are present, this will give rise to a parallel flux through the defect which transport mechanism is mainly determined by Knudsen diffusion and/or surface diffusion. However, the permeation according to these mechanisms decreases as function of temperature; therefore, the total apparent activation energy is decreased. The total activation energy can therefore be seen as a tool to judge membrane quality, provided no differences in sorption behavior occur.

Based on this procedure, silica-modified membranes that show apparent activation energies for
$\mathrm{H}_{2}$ permeation lower than ca. $3 \mathrm{~kJ} \mathrm{~mol}{ }^{-1}$, which is the case in roughly $25 \%$ of the cases, have been regarded as defect. These results have therefore not been included.

\subsection{Some separation results of silica-modified membranes}

Table 6 shows a presentation of the separation results of several silica-modified membranes, based on three-layer $\gamma$-alumina membranes. Data from Uhlhorn et al. [14] and from our previous paper [17], as well as membranes Al3-Sil-L and 
Table 6

Separation factors $\alpha$ for silica-modified membranes

\begin{tabular}{|c|c|c|c|c|c|c|c|}
\hline \multirow[t]{2}{*}{ Membrane } & \multirow[t]{2}{*}{ System } & \multicolumn{6}{|l|}{$\alpha$} \\
\hline & & $22^{\circ} \mathrm{C}$ & $50^{\circ} \mathrm{C}$ & $100^{\circ} \mathrm{C}$ & $150^{\circ} \mathrm{C}$ & $200^{\circ} \mathrm{C}$ & $250^{\circ} \mathrm{C}$ \\
\hline$A l 3-S i l-E^{a}$ & $\mathrm{H}_{2}$-propene & 13.4 & - & 62 & - & 156 & $>272^{b}$ \\
\hline $\mathrm{Al} 3-\mathrm{Sil}-\mathrm{F}^{\mathrm{a}}$ & $\mathrm{CO}_{2}-\mathrm{CH}_{4}$ & 48 & - & 65 & - & 28 & - \\
\hline $\mathrm{Al} 3-\mathrm{Si} 2-\mathrm{A} 1^{\circ}$ & $\mathrm{H}_{2}-\mathrm{CH}_{4}$ & 2 & 3 & 5 & 8 & 11 & 12 \\
\hline $\mathrm{Al} 3-\mathrm{Si} 2-\mathrm{A} 1^{\mathrm{c}}$ & $\mathrm{H}_{2}-\mathrm{CO}_{2}$ & 1.7 & - & 2.5 & 4.5 & 5.5 & 6.5 \\
\hline $\mathrm{A} 13-\mathrm{Si} 2-\mathrm{A} 2^{\mathrm{C}}$ & $\mathrm{H}_{2}-\mathrm{CH}_{4}$ & 2 & 3 & 5 & 10 & 18 & 30 \\
\hline $\mathrm{Al} 3-\mathrm{SiTi}^{\mathrm{c}}$ & $\mathrm{H}_{2}-\mathrm{CH}_{4}$ & 12 & 50 & 150 & 200 & 165 & - \\
\hline Al3-Sil-L & $\mathrm{H}_{2}-\mathrm{CH}_{4}$ & 6.3 & - & 17.2 & - & - & - \\
\hline Al3-Sil-M & $\mathrm{H}_{2}-\mathrm{CH}_{4}$ & 10 & 35 & - & - & - & - \\
\hline
\end{tabular}

a Data taken from Uhlhorn et al. [14].

b $T=260^{\circ} \mathrm{C}$.

${ }^{c}$ Data taken from Ref. [17].

Al3-Sil-M (three-step $\gamma$-alumina membranes, modified in a single step with microporous silica) are included. In combination with the separation results presented, some important membrane characteristics can be seen. The most direct observation is that the separation factor for $\mathrm{H}_{2}$ versus other molecules increases with increasing difference in molecular size; $\alpha_{\mathrm{H}_{2}-\mathrm{C}_{3} \mathrm{H}_{6}}>>\alpha_{\mathrm{H}_{2}-\mathrm{CH}_{4}}$ and $\alpha_{\mathrm{H}_{2}-\mathrm{CH}_{4}}>$ $\alpha_{\mathrm{H}_{2}-\mathrm{CO}_{2}}$. This effect is more pronounced at higher temperatures. In general, the $\mathrm{H}_{2}-\mathrm{C}_{x} \mathrm{H}_{y}$ separation factors increase with temperature. Some exceptions on these general trends, however, are observed. For example for membrane Al3-SiTi, where extremely high separation factors are found, an optimum in separation factor at $150^{\circ} \mathrm{C}$ is present.

The separation results after the first silica modification step are compared with those of the twolayer silica-modified membrane to evaluate the possibility of defect repair. Elimination of defects should lead to increased separation factors. The results of this second dipping of silica are shown in Table 7 for $\mathrm{H}_{2}-\mathrm{CH}_{4}$ separation and in Figs. 13 and 14 for $\mathrm{H}_{2}$-isobutane separation. The $\mathrm{H}_{2}-\mathrm{CH}_{4}$ separation for the membrane All-Si2-A (first step) is slightly higher than for membrane Al1-Sil-B, which was prepared in a single modification step according to the same procedure. The $\mathrm{H}_{2}-\mathrm{CH}_{4}$ separation is indeed improved after the second modification step, especially at higher temperatures. Because of this modification the permeation
Table 7

Permeation data of some sol-gel derived microporous membranes with different quality in combination with separation performance

\begin{tabular}{|c|c|c|c|c|}
\hline \multirow[t]{2}{*}{ Membrane } & \multirow{2}{*}{$\begin{array}{l}T \\
\left({ }^{\circ} \mathrm{C}\right)\end{array}$} & \multicolumn{3}{|c|}{ Permeation $F\left(10^{-2} \mathrm{~mol} \mathrm{~m}^{-2} \mathrm{~s}^{-1} \mathrm{~Pa}^{-1}\right.$} \\
\hline & & $\mathrm{H}_{2}$ & $\mathrm{CH}_{4}$ & $\alpha \mathrm{H}_{2}-\mathrm{CH}_{4}{ }^{\mathrm{a}}$ \\
\hline \multirow[t]{2}{*}{ All-Sil-B } & 50 & 20.8 & 3.9 & 5.5 \\
\hline & 200 & 21.6 & 3.9 & 5.5 \\
\hline \multicolumn{5}{|l|}{ Al1-Si2-A } \\
\hline \multirow[t]{2}{*}{ 1st step } & 50 & 18.6 & 5.1 & 6.6 \\
\hline & 200 & 24.6 & - & 6.0 \\
\hline \multirow[t]{2}{*}{ 2nd step } & 50 & 10.4 & - & 9.8 \\
\hline & 200 & 14.1 & - & 11.0 \\
\hline \multicolumn{5}{|l|}{ Al3-Si2-A ${ }^{b}$} \\
\hline \multirow[t]{3}{*}{ 1st step } & 50 & 3.7 & 1.8 & 3 \\
\hline & 200 & - & - & 11 \\
\hline & 300 & - & - & 11 \\
\hline \multirow[t]{3}{*}{ 2nd step } & 50 & 1.8 & - & 3 \\
\hline & 200 & 5.0 & - & 18 \\
\hline & 300 & - & - & 40 \\
\hline
\end{tabular}

a Obtained from separation experiments.

${ }^{\mathrm{b}}$ Data taken from Ref. [17].

rates (measured in the separation set-up, accuracy $20 \%$ ) are decreased by almost a factor of 2 .

Since the separation factor of $\mathrm{H}_{2}$-isobutane is already relatively high after the first silica modification, it can be concluded that no large defects, such as wide cracks or large pinholes can be 


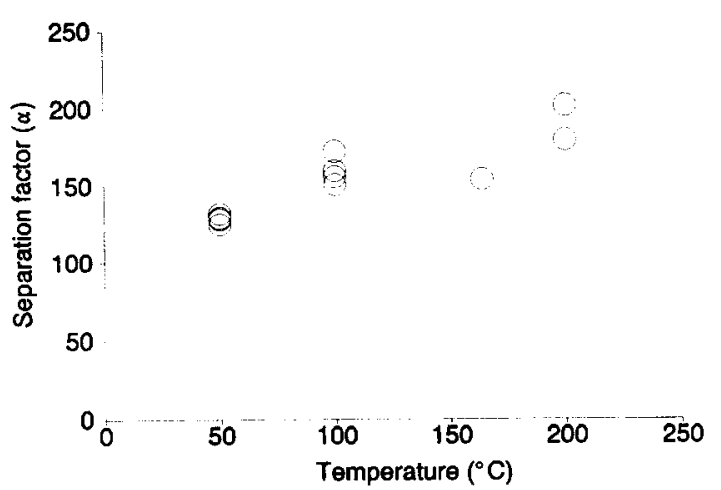

Fig. 13. $\mathrm{H}_{2}$-isobutane separation of silica-modified membrane All-Si2-A after the first modification step. $\Delta P=0.3 \mathrm{bar}, P_{\text {low }}=$ 0.8 bar. $\mathrm{H}_{2}$-isobutane feed $=200: 200 \mathrm{ml} / \mathrm{min}$.

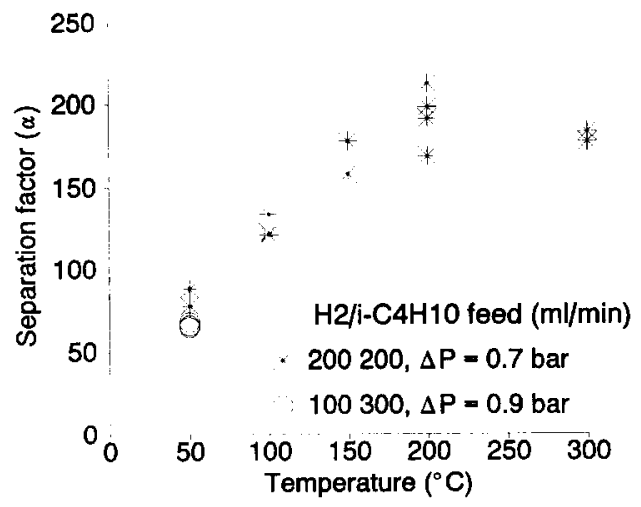

Fig. 14. $\mathbf{H}_{2}$-isobutane separation of silica-modified membrane Al1-Si2-A after the second modification step. $P_{\text {low }}=0.8$ bar.

present. The defects, which have been repaired after the second modification, are therefore very small ones which mainly improve the $\mathrm{H}_{2}-\mathrm{CH}_{4}$ separation and do not affect the $\mathrm{H}_{2}$-isobutane separation factor, since isobutane showed already a negligible permeation through these defects before the repair step.

\section{Discussion}

\subsection{Discussion of presented results in relation with membrane quality}

The variation in the presented non-corrected apparent activation energy for hydrogen permeation (Table 5 ) is roughly between 3 and
$15 \mathrm{~kJ} \mathrm{~mol}^{-1}$. The reproducibility of membrane preparation, leading to this variation in the results, is expected to be related to very small defects, such as microcracks or pinholes, in the top-layers. Since simultaneous gas transport through the pinholes or cracks is mainly determined by Knudsen diffusion, which contribution decreases as the temperature increases, the presence of cracks and pinholes will decrease the calculated activation energy for permeation.

When the apparent activation energy is used to judge the membrane quality, high-quality membranes are classified by an apparent activation energy for $\mathrm{H}_{2}$ higher than around $7-8 \mathrm{~kJ} \mathrm{~mol}^{-1}$ (corrected values). The arguments for this value are that high separation factors for $\mathrm{H}_{2}-\mathrm{CH}_{4}$ are obtained in these cases. For example, a separation factor of 40 at $300^{\circ} \mathrm{C}$ has been found for membrane Al3-Si2-A (after the second dipping procedure) with an apparent activation energy for hydrogen permeation of $7.1 \mathrm{~kJ} \mathrm{~mol}^{-1}$ (corrected $7.9 \mathrm{~kJ}$ $\mathrm{mol}^{-1}$ ). For membrane Al3-Sil-I, with a corrected activation energy of $7.4 \mathrm{~kJ} \mathrm{~mol}^{-1}$, high permselectivities, on the order of 77 at $200^{\circ} \mathrm{C}$ (corrected for support influence), have been found.

Also, an effect on the activation energies can be expected from wide-pore size distributions (PSDs) of the microporous top-layer. From the pore size calculations on non-supported microporous membranes it was found that the pore size distribution looks to be bimodal with a strong maximum at an effective diameter of $0.5 \mathrm{~nm}$ and a weaker maximum at $0.75 \mathrm{~nm}[20,38]$. Strong variations in the PSDs for freshly prepared non-supported silica membranes have not been observed, however. Consequently, the contribution to the variation in permeation data due to this effect is probably small.

The contribution of the maximum in the PSDs at an effective pore diameter of $0.75 \mathrm{~nm}$, however, may be important for separation. The effects on the separation properties of small variations can drastically influence separations by, for example, size exclusion mechanisms. Membranes with a relatively low quality, as defined by a separation factor for $\mathrm{H}_{2}-\mathrm{CH}_{4}$ on the order of 5 (which is still an improvement compared with that of Knudsen by at least a factor 2), show a surprisingly high 
separation capacity for $\mathrm{H}_{2}$-isobutane on the order of 100-200. The presence of the defects in these membranes seems to be less important for the $\mathrm{H}_{2}-$ isobutane separation.

Therefore, it can be concluded that the defects that are present, and result in low separation factors for $\mathrm{H}_{2}-\mathrm{CH}_{4}$, are very small and might be regarded as little wider micropores, since the $\mathrm{H}_{2}$-isobutane separation is not significantly affected.

This is a very important characteristic since for dehydrogenation applications in membrane reactors it is mainly interesting to separate $\mathrm{H}_{2}$ from higher alkanes, with preferably high permeation rates. It is therefore not necessary to apply membranes with superior quality.

\subsection{Discussion of presented permeation and separation results}

For membrane Al3-Sil-I (Figs. 3-8, Table 2) it is clearly shown that activated transport (corrected $\mathrm{H}_{2}$ apparent activation energy $=7.4 \mathrm{~kJ} \mathrm{~mol}^{-1}$ ) is accompanied by molecular sieve-like permeation. The order in permeation rates is $\mathrm{H}_{2}>\mathrm{CO}_{2}>$ $\mathrm{O}_{2}>\mathrm{N}_{2}>\mathrm{CH}_{4}$, which is equal to the order in kinetic diameter.

From the $\mathrm{CO}_{2}$ data it is shown that the use of permeation, defined as flow per unit of pressure, to describe the transport behavior, is useful only if Henry sorption behavior occurs in the measurement range used. If Langmuir sorption takes place, the surface concentration and, consequently, the membrane flow are not linearly dependent on pressure. The permeation of the top-layer, defined as flow per unit of pressure, then decreases with pressure, and Eqs. 1 and 2 cannot be used in the way as discussed. In Fig. 6 it can be seen that at low temperatures there is a slight decrease in the $\mathrm{CO}_{2}$ permeation, whereas this pressure dependence is absent at higher temperatures. Indeed it has been found that Henry sorption behavior with $\mathrm{CO}_{2}$ on silica, for a pressure range between 0 and 2 bar, occurs only at temperatures exceeding $50^{\circ} \mathrm{C}$ [39]. Below this temperature, $\mathrm{CO}_{2}$ sorption shows some slight non-linearity on pressure and can be described according to Langmuir sorption.

The calculated permselectivities are considerably higher than those for Knudsen diffusion. The (corrected) Arrhenius plot of hydrogen permeation (Fig. 9), measured for temperatures between 29 and $300^{\circ} \mathrm{C}$, shows an almost perfect linearity. This linearity is also found for other membranes. The linearity of the Arrhenius plots leads to the conclusion that very likely no change in permeation mechanism takes place in the temperature range studied. When the rate-determining step for a process changes, this usually results in a change of the activation energy provided the activation energies characteristic of the mechanisms under discussion differ significantly.

When discussing the actually calculated (corrected for support influence) activation energies, it has to be recognized that these are apparent activation energies, since they contain a contribution from sorption and micropore diffusion, as can be seen from Eq. 2. The characteristic activation energies of these are, respectively, the isosteric heat of adsorption ( $q^{\text {st }}$, Eq. 5) and the activation energy for micropore diffusion ( $\left.E_{1}, \mathrm{Eq} .3\right)$.

Membrane All-Sil-A (Figs. 10-12, Table 4), prepared by modification of a single-layer $\gamma$-alumina membrane, shows activated transport for $\mathrm{H}_{2}$ and $\mathrm{CH}_{4}$, with an apparent activation of $5.4 \mathrm{~kJ} \mathrm{~mol}^{-1}$ for $\mathrm{H}_{2}$. Comparison with the data in Table 5 shows that this result does not indicate that the transport properties of this membrane are different from those of microporous membranes prepared by modification of three-layer $\gamma$-alumina membranes. The $\mathrm{CO}_{2}, \mathrm{O}_{2}$ and isobutane permeation, however, decrease as function of temperature.

This is due to the fact that the apparent activation energy for carbon dioxide is always considerably lower than the apparent activation energy for hydrogen. Only for high-quality membranes with an activation energy for hydrogen permeation of ca. $7 \mathrm{~kJ} \mathrm{~mol}^{-1}$ or higher, carbon dioxide shows activated transport. As will be shown [39], this is caused by the higher isosteric heat of adsorption for carbon dioxide on silica than for hydrogen ( 22 and $6 \mathrm{~kJ} \mathrm{~mol}^{-1}$ respectively). This results in a stronger decrease of the concentration in the micropores compared to hydrogen as the temperature is increased. From Eq. 2 it can then be seen that this will lead to a lower activation energy for 
permeation, or even to decreasing permeation as a function of temperature.

Since the isosteric heat of isobutane is $23 \mathrm{~kJ} \mathrm{~mol}^{-1}$ [40], this explains also the decreasing isobutane permeation for membrane All-Sil-A. The isobutane permeation for this membrane also decreases with pressure (Fig. 12). This is caused by deviation from the Henry sorption behavior under these conditions [40].

In Table 5 it can be seen that the hydrogen permeation rates at $200^{\circ} \mathrm{C}$ are between $12 \cdot 10^{-7}$ and $23 \cdot 10^{-7} \mathrm{~mol} \mathrm{~m} \mathrm{~m}^{-2} \mathrm{~s}^{-1} \mathrm{~Pa}^{-1}$, but no direct correlation with membrane quality (determined by the hydrogen activation energy) seems to be present. Relatively high permeation rates on the order of $20 \cdot 10^{-7} \mathrm{~mol} \mathrm{~m}^{-2} \mathrm{~s}^{-1} \mathrm{~Pa}^{-1}$ have been found for both a membrane with an exceptional high activation energy for hydrogen of $21.7 \mathrm{~kJ} \mathrm{~mol}^{-1}$ (corrected) and a membrane with a low activation energy of $6.6 \mathrm{~kJ} \mathrm{~mol}^{-1}$ (corrected). This may be attributed to layer thickness effects. As observed [17], the layer thickness variation of silica-modified membranes is between 60 and $120 \mathrm{~nm}$.

The influence of the support determines partly the large difference between the $\mathrm{H}_{2}-\mathrm{CH}_{4}$ and $\mathrm{H}_{2}$-isobutane separation factors for the same membrane. For membranes with $\mathrm{H}_{2}$-isobutane separation factors of ca. $100-200$, the $\mathrm{H}_{2}-\mathrm{CH}_{4}$ separation factor is between 3 and 11 (Figs. 13 and 14, Table 7). The ideal Knudsen separation factor for the support is 5.39 for $\mathrm{H}_{2}$-isobutane and 2.83 for $\mathrm{H}_{2}-\mathrm{CH}_{4}$. The combined effect of the top layer separation factor $\left(\alpha_{t}\right)$ and the support ( $\equiv \gamma$-alumina membrane) separation factor $\left(\alpha_{s}\right)$ on the total separation factor $(\alpha)$ can be expressed as [49]:

$\alpha=\alpha_{\mathrm{s}} \alpha_{t}$

Since the support separation factor for $\mathrm{H}_{2}$-isobutane is a factor 2 higher than for $\mathrm{H}_{2}-\mathrm{CH}_{4}$, the actually found separation factor of the top-layer for $\mathrm{H}_{2}$-isobutane is stronger enhanced than for $\mathrm{H}_{2}-\mathrm{CH}_{4}$. It has to be noted, however, that for high-quality membranes the actual effect of the support is very low, and of very minor influence. Since in these cases the pressure drop over the support ( $\gamma$-alumina membrane) is very low, the separation factor of the support can decrease to values close to 1 due to increased back-diffusion into the support [49]. This means that the actually found separation factor is mainly a characteristic of the microporous top-layer in cases where the pressure drop is mainly across this top-layer.

The permselectivities for $\mathrm{H}_{2}-\mathrm{CH}_{4}$, as calculated in Table 2, are generally high compared to the actually found selectivities from the separation experiments. Two main effects are responsible for this phenomenon. Firstly, separation experiments are much more sensitive towards defects in the membrane than permeation measurements. Small leaks due to defects will not influence the permeation rate significantly, while the separation factor decreases strongly. Secondly, as discussed before, process parameters such as back-diffusion may occur in the separation configuration, resulting in lower separation factors [49].

The influence of changing feed pressure of the $\mathrm{H}_{2}-\mathrm{CH}_{4}$ gas mixture on separation is not large. This indicates that the relative transport rates have not changed and that the pressure increase influences both the $\mathrm{H}_{2}$ flow and the $\mathrm{CH}_{4}$ flow equally strong. The change in feed composition for $\mathrm{H}_{2}$-isobutane separation in Fig. 14 shows a slight decrease of separation factor (from 83 to 68) due to a change in $\mathrm{H}_{2}$-isobutane feed composition from 200:200 to $100: 300 \mathrm{ml} \mathrm{min}^{-1}$ and a slight increase in pressure difference. Obviously, the isobutane flow is enhanced with respect to the hydrogen flow. This is very likely related to the higher Henry coefficient $(K)$ of isobutane compared with that of hydrogen at these temperatures: $K=2.9 \cdot 10^{-5} \mathrm{~mol} \mathrm{~kg}^{-1} \mathrm{~Pa}^{-1}$ and $K<1.8 \cdot 10^{-7} \mathrm{~mol}$ $\mathrm{kg}^{-1} \mathrm{~Pa}^{-1}$ for isobutane and hydrogen, respectively [39]. When the flux is indeed proportional to the concentration in the pores, as expressed by Eq. 2, the isobutane flux increases stronger than the hydrogen flux. Outside the Henry region for isobutane (at low temperatures and/or high pressures), even total blocking of the pores for hydrogen may be possible.

The observations presented in Table 7 , where it can be seen that membranes with a high separation factor have in general relatively low permeation rates, can be explained by the presence or absence of defects ( $\equiv$ cracks, pinholes and/or wider micro- 
pores) in the top-layer. The second modification, with a very diluted dip solution, repairs these defects, resulting in lower permeation rates and higher separation factors. The improvement of the $\mathrm{H}_{2}-\mathrm{CH}_{4}$ selectivity due to the second modification for membrane Al1-Si2-A is about a factor 2 . Membrane Al3-Si2-A, however, has shown a significantly larger improvement of the $\mathrm{H}_{2}-\mathrm{CH}_{4}$ separation factor at $300^{\circ} \mathrm{C}$ from 11 to 40 [17]. This difference may be related to the fact that membrane surfaces are damaged by removing them from the permeation cell. Because the membranes are sealed on the top-layer with O-rings, the top-layer surface will be damaged at the place where it is in contact with the sealing. This damage varies from case to case and may cause some additional leaking when the sealing in the experiments after the second modification does not cover these damaged spots.

The results for the membranes obtained by modification of single-layer $\gamma$-alumina membranes do basically not differ from the results for microporous membranes obtained by modification of three-layer $\gamma$-alumina membranes. Membrane All-Si1-A (Figs. 10-12) showed activated transport for hydrogen with an activation energy of $11.1 \mathrm{~kJ} \mathrm{~mol}^{-1}$ (corrected). The permeation data for the other gases are comparable for three-layer $\gamma$-alumina membranes with a comparable activation energy for hydrogen. The separation results for Al1-Sil-B and Al1-Si2-A neither show different properties compared to silica-modified three layer $\gamma$-alumina membranes. These results suggest that the elimination of the second $\gamma$-alumina dipping step in the microporous membrane synthesis process is in principle possible. This is very advantageous from an economical and technological point of view, since it reduces the cost of the membranes, but also the support resistance. However, one has to recognize that this is strongly dependent on the used support quality, which must be high.

\section{Conclusions}

Gas transport through sol-gel derived microporous membranes is activated and shows molecular sieve-like separation properties with relatively high permeation rates. The order of permeation rates for the gases used follows the order of the kinetic diameters.

Typical apparent activation energies for permeation of the microporous top-layer, after correction for support influence, for $\mathrm{H}_{2}$ and $\mathrm{CO}_{2}$ are 17-22 and $10-15 \mathrm{~kJ} \mathrm{~mol}^{-1}$, respectively, for high-quality membranes. Permeation rates for hydrogen at $200^{\circ} \mathrm{C}$ are typically $20 \cdot 10^{-7}$ and $5 \cdot 10^{-7} \mathrm{~mol}$ $\mathrm{m}^{-2} \mathrm{~s}^{-1} \mathrm{~Pa}^{-1}$ for $\mathrm{CO}_{2}$.

In order to calculate the activation energy for micropore diffusion, for a further study of the transport mechanism, sorption phenomena have to be included.

Separation factors are on the order of 40 for $\mathrm{H}_{2}-\mathrm{CH}_{4}$ and 200 for $\mathrm{H}_{2}$-isobutane at $200-300^{\circ} \mathrm{C}$ for high-quality membranes. Defects in moderatequality membranes result in separation factors of 5-10 for $\mathrm{H}_{2}-\mathrm{CH}_{4}$, but to quite high separation factors on the order of $100-120$ for $\mathrm{H}_{2}$-isobutane at $200-300^{\circ} \mathrm{C}$. The defects are therefore very small and may be identical to some wider micropores.

The combination of high permeation rates and separation factors make these membranes very attractive for gas separation applications and/or for incorporation in membrane reactors.

\section{Acknowledgements}

Special thanks are due to J.H.A. Hekkink for performing many of the permeation measurements and to G.J.M. Weierink for his help with the GC analysis.

\section{References}

[1] K.S.W. Sing, D.H. Everett, R.A.W. Haul, L. Moscou, R.A. Pierotti, J. Rouquérol and T. Siemiewska, Pure Appl. Chem., 57 (1985) 603.

[2] R.R. Bhave, Inorganic Membranes: Synthesis, Characteristics and Applications, Van Nostrand Reinhold, New York, NY, 1991.

[3] K. Keizer, R.J.R. Uhlhorn, V.T. Zaspalis and A.J. Burggraaf, Key Eng. Mater., 61-62 (1991) 143.

[4] A.J. Burggraaf, K. Keizer, R.S.A. de Lange, Z.A.E.P. Vroon and V.T. Zaspalis, in J.B. Higgins, R. von Balmoos and M.M.J. Treacy (Eds.), Ceramic Membranes for Separations and Reactions, Butterworth-Heinemann, Stoneham, MA, 1993, p. 47. 
[5] D.E. Fain, Key Eng. Mater, , 61-62 (1991) 327.

[6] V.T. Zaspalis, K. Keizer, J.R.H. Ross and A.J. Burggraaf, Key Eng. Mater., 61-62 (1991) 359.

[7] V.T. Zaspalis, W. van Praag, K. Keizer, J.G. van Ommen, J.R.H. Ross and A.J. Burggraaf, Appl. Catal, 74 (1991) 205.

[8] V.T. Zaspalis, W. van Praag, K. Keizer, J.G. van Ommen, J.R.H. Ross and A.J. Burggraaf, Appl. Catal, 74 (1991) 223.

[9] V.T. Zaspalis, W. van Praag, K. Keizer, J.G. van Ommen, J.R.H. Ross and A.J. Burggraaf, Appl. Catal., 74 (1991) 235.

[10] V.T. Zaspalis, W. van Praag, K. Keizer, J.G. van Ommen, J.R.H. Ross and A.J. Burggraaf, Appl. Catal., 74 (1991) 249.

[11] R.D. Noble and J.N. Armor (Eds.), Special issue on membrane catalysis, Appl. Catal. A: General, 69 (1993).

[12] V.T. Zaspalis, K. Keizer, A.J. Burggraaf and M.P. Harold, in A. Holmen, B.F. Magnussen and F. Steinike (Eds.), Proceedings of The European Applied Research Conference on Natural Gas (Eurogas). Trondheim, 1992, p. A143.

[13] K. Keizer, V.T. Zaspalis, R.S.A. de Lange, M.P. Harold and A.J. Burggraaf, in J. Crespo and K. Bödekker (Eds.), Membrane Processes and Separation and Purification, Kluwer Academic Publishers, Dordrecht, 1994, in press.

[14] R.J.R. Uhlhorn, K. Keizer and A.J. Burggraaf, J. Membrane Sci., 66 (1992) 271.

[15] S. Kitao, H. Kameda and M. Asaeda, Membrane, 15 (1990) 222.

[16] R.S.A. de Lange, J.H.A. Hekkink, K. Keizer and A.J. Burggraaf, in M.J. Hampden-Smith, W.G. Klemperer and C.J. Brinker (Eds.), Better Ceramics through Chemistry $V$ (Mater, Res. Symp. Proc., Vol. 271). Materials Research Society, Pittsburgh, PA, 1992, p. 505.

[17] R.S.A. de Lange, J.H.A. Hekkink, K. Keizer and A.J. Burggraaf, $J$. Membrane Sci, in press.

[18] C.J. Brinker, T.L. Ward, R. Sehgal, N.K. Raman, S.L. Hietala, D.M. Smith, D.-W. Hua and T.J. Headley, J. Membrane Sci., 77 (1993) 165.

[19] R.S.A. de Lange, K-N.P. Kumar, J.H.A. Hekkink, G.M.H. van de Velde, K. Keizer, A.J. Burggraaf, W.H. Dokter, H.F. van Garderen and T.P.M. Beelen, J. Sol-Gel Sci. Technol, 2 (1994) 489.

[20] R.S.A. de Lange, Ph.D. Thesis, University of Twente, Enschede, 1993.

[21] R.K. Iler, The Chemistry of Silica, John Wiley and Sons, New York, NY, 1979.

[22] G.R. Gavalas, C.E. Megiris and S.W. Nam, Chem. Eng. Sci., 44 (1989) 1829.

[23] R.S.A. de Lange, J.H.A. Hekkink, K. Keizer and A.J. Burggraaf, Ind. Eng. Chem. Res., submitted for publication.

[24] T. Okubo and H. Inoue, AIChE J., 35 (1989) 845.

[25] M. Tsapatsis, S. Kim, S.W. Nam and G. Gavalas, Ind. Eng. Chem. Res., 30 (1991) 2152.
[26] S. Kitao and M. Asaeda, Key Eng. Mater., 61-62 (1991) 267.

[27] C.E. Megiris and J.H.E. Glezer, Ind. Eng. Chem. Res.. 31 (1992) 1293.

[28] Y.S. Lin and A.J. Burggraaf, AIChE J., 38 (1992) 445.

[29] Y.S. Lin and A.J. Burggraaf, J. Membrane Sci., 79 (1993) 65.

[30] M. Bhandarkar, A.B. Shelekhin, A.G. Dixon and Y.H. Ma, J. Membrane Sci., 75 (1992) 221.

[31] A.B. Shelekhin, A.G. Dixon and Y.H. Ma, J. Membrane Sci., 75 (1992) 232.

[32] E.R. Geus, M.J. den Exter and H. van Bekkum, J. Chem. Soc. Faraday Trans, 88 (1992) 3102.

[33] W.J.W. Bakker, G. Zheng, F. Kapteijn, M. Makkee, J.A. Moulijn, E.R. Geus and H. van Bekkum, in M.P.C. Weynen and A.A.H. Drinkenburg (Eds.), Precision Process Technology: Perspectives for Pollution Prevention, Kluwer Academic Publishers, Dordrecht, 1993, p. 425.

[34] E.R. Geus, Ph.D. Thesis, Technical University of Delft. Delft, 1993

[35] M.D. Jia, K.V. Peinemann and R.D. Behling, J. Membrane Sci., 82 (1993) 15.

[36] Z.A.E.P. Vroon, M.J. Gilde, K. Keizer and A.J. Burggraaf, Membraantechnologie, (1994) in press.

[37] R.S.A. de Lange, J.H.A. Hekkink, K. Keizer and A.J. Burggraaf, J. Non-Cryst. Solids, submitted for publication.

[38] R.S.A. de Lange, J.H.A. Hekkink, K. Keizer and A.J. Burggraaf, J. Non-Cryst. Solids, submitted for publication.

[39] R.S.A. de Lange, K. Keizer and A.J. Burggraaf, $J$. Membrane $S_{c i}$, in press.

[40] R.S.A. de Lange, J.H.A. Hekkink, K. Keizer, Y.H. Ma and A.J. Burggraaf, Microporous Mater, submitted for publication.

[41] J. Kärger and D.M. Ruthven, Diffusion in Zeolites and other Microporous Materials, John Wiley and Sons, New York, NY, 1992.

[42] M.F.M. Post, in H. van Bekkum, E.M. Flanigen and J.C. Jansen (Eds.), Introduction to Zeolite Science and Practice. Elsevier, Amsterdam, 1991, p. 391.

[43] R.M. Barrer, J. Chem. Soc. Faraday Trans., 86 (1990) 1123.

[44] R.J.R. Uhlhorn and A.J. Burggraaf, in R.R. Bhave (Ed.), Inorganic Membranes; Synthesis, Characteristics and Applications, Van Nostrand Reinhold, New York, NY. 1991, p. 155.

[45] R.J.R. Uhlhorn, Ph. D. Thesis, University of Twente, Enschede, 1990.

[46] E. Gilliland, R.F. Baddour and G.P. Perkinson, Ind. Eng. Fundum., 13 (1974) 95.

[47] R.J.R. Uhlhorn, K. Keizer and A.J. Burggraaf, J. Membrane Sci., 66 (1992) 259.

[48] R. Krishna, Gas Sep. Purif., 7 (1993) 91.

[49] K. Keizer. R.J.R. Uhlhorn, R.J. van Vuren and A.J. Burggraaf, J. Membrane Sci., 39 (1988) 285. 
[50] A.F.M. Leenaars, K. Keizer and A.J. Burggraaf, J. Mater Sci., 19 (1984) 1077.

[51] A.F.M. Leenaars, K. Keizer and A.J. Burggraaf, J. Colloid Interface Sci., 105 (1985) 27.

[52] ASTM Standards, Standard Test Method for Determining Gas Permeability Characteristics of Plastic Film and Sheeting, Designation D1434-82, Section 15, General
Products, Chemical Specialities, and End Use Products, ASTM, Philadelphia, PA, 1989, p. 255.

[53] Y.S. Lin and A.J. Burggraaf, J. Am. Ceram. Soc., 74 (1991) 219.

[54] D.W. Breck, Zeolite Molecular Sieves; Structure, Chemistry and Use, John Wiley and Sons, New York, NY, 1973, p. 636. 